\title{
Increasing the Students' Civics Learning Results by Using Paired Reading Model
}

\author{
Guntoro, Aminuddin Kasdi, Wahyu Sukartiningsih \\ Universitas Negeri Surabaya \\ Surabaya, Indonesia \\ ahmadguntoro320@gmail.com
}

\begin{abstract}
This study aimed to improve the unsuccessful students in Civics learning process. The subjects in this study were the students of grade V SDN Kuwon 1, Kec. Karas, Magetan. This research used a Classroom Action Research (CAR) design with 2 cycle due to the suitability with the learning objective that is to improve the students' ability in Civics by using Paired Reading Model. The results showed that the students can improve not only their ability in the process of learning Civics but also their interest in understanding the Civics material after the Paired Reading Model was implemented in the class. This learning model is seen as the effective and efficient learning model to be implemented in Civics learning process.
\end{abstract}

\section{Keywords-Paired Reading Model, Learning Outcomes}

\section{INTRODUCTION}

The tasks of teachers in teaching Civics to their students are to develop civic intelligence in the dimension of spiritual, rational, emotional, and social, to develop the students' participation as the citizens (civic responsibility), to develop the protégés participation as the citizens (civic intelligence) in order to be able to sustain the growth and development of good citizens. The mastery of Civics materials for students is grown by developing several strategies that involve the students' activeness in the learning process [1].

The students' mastery of a certain subject is usually expressed by a value [2]. In the Civics learning process of a certain subject, there is a standard value that indicates the low mastery of students related to this subject matter. It is known by the existence of student value data from the evaluation result which shows only the 6 students from 24 students of class V SDN Kuwon 1, Kec. Karas, Kab. Magetan who reached the level of mastery of the material by $70 \%$ and above. The students who got the low mastery level of Civics material were failed in the topic about the understanding of regulations at Central and Regional level. Thus, the researchers as the teachers take the initiative to change the the unsuccessful learning system by implementing the learning improvement in the class.

This classroom action research that aimed at the improvement of the learning process in the class should follow some steps they are planning, implementation, observation, and reflection. Based on the reflection that was done together with the colleagues and supervisors, the problems of the students involve,

1. The students are inability to master the learning materials.

2. The students have a low interest in the learning materials.

\section{METHOD}

1. Understanding

[3] The Paired Reading Model is part of the Interactive Group models that take the role as the umbrella of a group of learning models that organize the learning activities in various forms of social interaction in small or large groups [4].

2. Paired Reading Model Procedures

The procedure of using Paired Reading Model is presented as follows:

1. Determine the reading pair of students.

2. Determine the material to be read in pairs.

3. Complete the paired reading.

3. The relation between the learning outcomes and Paired Reading Model

[5] Learning outcomes are the better process of knowledge change gained from a learning experience or following a particular subject in a certain period of time. It usually expressed by a value generally in the form of figures that the teacher made after having the student learning evaluation. Learning experience here is defined as a process of teaching and learning activities in order to be able to achieve the learning objectives. The process is strongly influenced by the alternative teaching methods or models used by the teachers.

Teaching model or method is a way that the teachers use in interacting or communicating with their students in the learning process. Each model or method has different characteristics in shaping the learning experience of the students [6].

In the implementation of Paired Reading Model, the process is supported by a discussion to clarify the understanding contained in the discourse. So, the Paired Reading Model is believed by the researchers to improve the students learning outcomes in the process of teaching and learning Civics than the other learning models due to 
the needs of the class atmosphere that is requires a good communication and synergy skills between the teachers and the students.

After the data are obtained, the next step is analyze the data. The data of this research are obtained from the students' test of learning achievement and classroom observation.

The analytical technique used by the researcher in this research is descriptive quantitative analysis by determining the average value and percentage. Furthermore, based on the results of the analysis, the researchers can determine or arrange an interpretation of the research [7].

Daily teaching and learning activities done by the teachers must not be separated from the use of learning methods in an attempt to achieve the learning objectives, although sometimes there are not directed because of lack of preparation and planning. However, the teachers in order to be able to success in conducting the teaching and learning activities must implement a learning method or model that is appropriate with the classroom situation and condition. Therefore, the teacher must be clever in choosing it [8].

The following are the reasons to use Paired Reading Model:

1. Paired Reading Model can ease the students in grasping the notion of written material.

2. Through the Paired Reading Model, the students are expected to be able to understand the learning material faster.

3. A discussion is held in this model with these following steps:

a. Formulate the problem based on the topic of discussion and learning objectives,

b. Identify the problem,

c. Analyze the problem,

d. Discuss the problem/ topic, reports,

e. Present the results in groups,

f. Sum up the results of the discussion

\section{RESULTS AND DISCUSSION}

The results of each cycle

The steps taken to improve the students' Civics learning for the cycle I were presented as follows [9]:

a. Create a Lesson Plan of Improvement (RPP) as the action to be implemented.

b. Prepare well-structured, systematic and complete learning materials for each step of learning activities with a variety of methods.

c. Prepare the facilities and supporting facilities required in the form of props, written materials, books and worksheets.

d. Prepare the instruments to capture the data related to the process they are some evaluation tests and records. e. In accordance with the research problems encountered, namely the low achievement of students, the less learning interest of students, the low mastery of the material on the subject matter of Civics with topic "Understanding Legislation Central Level and Regional Level", some special activities concerning the learning improvement held after reading in pairs to motivate and keep the students' concentration during reading in pairs and guide students to play an active role in the discussions.

Implementation

The steps taken to improve the students' Civic learning in cycle I were presented as follows:

a. The teacher divides the students by pairing and giving written material for reading in pairs.

b. The teacher sets the students into 5 groups and each group discusses the results from the reading by looking for the differences between the definition of central and local level legislation.

c. The teacher asks the representatives of each group to present the results of the discussion.

d. The teacher discusses the results of the discussion and concludes the subject matter.

e. The teacher provides an evaluation at the end of the lesson.

f. The teacher collects the data during the learning activities assisted by peers.

g. The teacher reflects the activities done in the class by trying to reflect on what has been done and its impact on the students in the learning process.

\section{CONCLUSION}

Based on the results of this research, there are some improvement should be done in the teaching and learning process by the teachers they are:

1. Finding and choosing methods/ models that fit and in accordance with the learning process in order to facilitate the students in understanding the subject matter.

2. Choosing a variety of methods to be implemented in each lesson to avoid the students' boredom and to increase the students' learning interests [10].

Based on the improvement of learning that has been implemented in cycle I and cycle II, it can be concluded that:

1. The improvement of learning by applying Paired Reading Model is very effective and efficient to improve the students' achievement and interest that are proved by the average value and the percentage of the student's learning mastery in cycle I and II, that is: cycle I result of average evaluation value is 73.2 ; the percentage of students who complete is $72 \%$ and in the cycle II, the average evaluation of the results is 78.8 ; the percentage of students who complete is $92 \%$. 
2. Paired Reading Model is very good and effective when it is applied in the learning process that requires an understanding of concept because the emphasis of this model is the communication and synergy skills between the teacher and the students.

3. In the learning process, the students need a variety of learning methods/ models to avoid boredom.

4. Discussion methods that are part of the Paired Reading Model have a very positive impact on the students' understanding of the material being taught as it serves to clarify the understanding contained in the discourse.

\section{DISCUSSION}

To clarify further the results of the research that has been implemented, the researchers discuss the cycle I and II, as follows:

1. The discussion of Cycle I
a. The student learning outcomes
b. The ability in managing the learning process
c. The teacher and students' activities in the learning process

2. The discussion of Cycle II
a. The students' learning activity
b. The ability in managing the learning process
c. The teacher and students' activities in the learning process

\section{REFERENCES}

[1] U. S. Winataputra, R. Rahmat, S. Sapriya, H. Sumardi, S. Mikdar, K. Wihardit, et al., "Materi dan pembelajaran PKn SD," 2014.

[2] U. S. Winaputra, "Materi dan pembelajaran pkn SD," Jakarta: Universitas Terbuka, 2008.

[3] K. E. Stanovich, "Toward an interactive-compensatory model of individual differences in the development of reading fluency," Reading research quarterly, pp. 32-71, 1980.

[4] A. Arsyad, "Media pembelajaran," ed: Jakarta: PT Raja Grafindo Persada, 2011.

[5] Y. A. Muhaimin, "Kamus Besar Bahasa Indonesia Edisi Ketiga," Jakarta: Departemen Pendidikan Nasional Balai Pustaka, 2000.

[6] H. Hendriana, E. E. Rohaeti, and W. Hidayat, "Metaphorical Thinking Learning and Junior High School Teachers' Mathematical Questioning Ability," Journal on Mathematics Education, vol. 8, pp. 55-64, 2017.

[7] J. Sarwono, M. Arikunto, and M. S. Arikunto, "Metode Penelitian," Kuantitatif Kualitatif, 2006.

[8] S. B. Djamarah and A. Zain, "Strategi belajar mengajar," Jakarta: Rineka Cipta, 2006.

[9] N. Roestiyah and Y. Suharto, Strategi belajar mengajar: PT. Bina Aksara, Jakarta, 1985.

[10] A. Sudijono, Pengantar statistik pendidikan: PT Raja Grafindo Persada, 2005. 